\title{
Pharmacognostical characterization and formulation of herbal-based low-cost mosquito repellents from Elettaria cardamomum (Linn.) seed by using natural binder
}

\author{
Rajat Das ${ }^{1}$, Prosanta Pal ${ }^{2}$ and Sonam Bhutia ${ }^{3^{*}}$ (D)
}

\begin{abstract}
Background: In the present scenario, the markets are flooded with chemical-based mosquito repellent products that are proven to be toxic to the human life especially to the children and quite expensive in term of cost. This present investigation was attempted to evaluate the complete pharmacognostical characteristics of Elettaria cardamomum (Linn.) seed and to formulate eco-friendly and cost-effective herbal mosquito repellents of the seed powder by using a natural binder.

Results: The results of microscopic study of seed confirmed the presence of perisperm, embryo, endosperm and testa (Figs. 4, 5 and 6). The extractive values, moisture contents and ash values were also analysed and found to be alcoholic extract, 4.88\% w/W; water extract, $40 \% \mathrm{w} / \mathrm{w}$; moisture content, 8.6\%; total ash, 5\% w/w; acid insoluble ash, $1.5 \% \mathrm{w} / \mathrm{w}$; and water soluble ash, 3.5\% w/w (summarized in Tables 1, 2 and 3). From the mosquito repellency test (Table 6), the combination of cardamom seed cake was done with cardamom powder 3/2 + 1/4 spoons, wood powder 3 spoons and chilli powder 1/4 spoon which showed low residual percentage of 15.05\%, no irritation and an average burning time of $65 \mathrm{~min}$. The formulated herbal-based mosquito repellents were found to be more effective without any side effects and found less cost too.

Conclusion: All the ingredients used in the formulation were herbal based and has no side effect on human health. The cost of the cake was Rs. 11.332/- and it can be considered as good mosquito repellent cakes because of its consistent burning ability with no irritating smoke and low residual percentage and high mosquito repellent ability. By utilizing this concept, the researchers can develop herbal, eco-friendly and cost-effective mosquito repellents in future.
\end{abstract}

Keywords: Elettaria cardamomum (Linn.) seed, Pharmacognostical evaluation, Mosquito repellent, Herbal based, Cost-effective

\footnotetext{
* Correspondence: sonamkzbhutia@gmail.com

${ }^{3}$ Department of Pharmacognosy, Government Pharmacy College, Government of Sikkim, Sikkim University, Sajong, Rumtek, East Sikkim, Gangtok 737135, India

Full list of author information is available at the end of the article
}

\section{Springer Open}

(c) The Author(s). 2021 Open Access This article is licensed under a Creative Commons Attribution 4.0 International License, which permits use, sharing, adaptation, distribution and reproduction in any medium or format, as long as you give appropriate credit to the original author(s) and the source, provide a link to the Creative Commons licence, and indicate if changes were made. The images or other third party material in this article are included in the article's Creative Commons licence, unless indicated otherwise in a credit line to the material. If material is not included in the article's Creative Commons licence and your intended use is not permitted by statutory regulation or exceeds the permitted use, you will need to obtain permission directly from the copyright holder. To view a copy of this licence, visit http://creativecommons.org/licenses/by/4.0/. 


\section{Background}

Mosquitoes are belonging to the family Culicidae of the order Diptera, and they are similar in physical characteristics to other flies. However, many important characteristics of anophelines (Anopheles spp.) differ from the culicinae [1, 2]. Repellents make a mosquito unappealing to humans, so that parts of the body that have been handled with the chemical are avoided. Mosquitos are not destroyed by repellents. With a single application, the better repellents can provide protection from bites for a prolonged period of time ( $>1 \mathrm{~h}$ ). Many plants produce compounds that are used by phytophagous (plant eating) insects to avoid attacks. These chemicals, including repellents, feeding deterrents, contaminants and growth regulators, fall into several groups. The majority can be classified into five main chemical categories: nitrogen compounds (primarily alkaloids), terpenoids, proteinase inhibitors, phenolics and growth regulators [3]. The currently available repellents are either synthetic chemicals such as DEET-N,N-Diethyl-meta-toluamide, picaridin and IR3535-Insect repellent IR3535, or chemicals extracted from plants such as citronella and eucalyptus lemon oil. There are different formulations available for these repellents that vary in the volume of the active ingredient, which is the material that actually repels the mosquito [4]. Insect repellents in different types and concentrations are available. For skin applications as well as for clothing care, aerosol and pump-spray items are intended. Products with liquid, cream, lotion, spray and stick allow direct skin application. For circumstances where exposure to insects is limited, items with low concentrations of active ingredients may be suitable. In heavily infested areas or with insect species that are more difficult to repel, higher concentrations of active ingredients may be useful [5]. Elettaria cardamomum (cardamom) is an evergreen shrub in the Zingiberaceae family (Fig. 1). As a spice, the seeds are used. It is regarded as the queen of spices. It ranks third in the worldwide list of expensive spices, followed by saffron and vanilla. Cardamom's medicinal usage is also listed in the Unani and Ayurveda systems. Cardamom also has a broad range of therapeutic characteristics such as antifungal, antibacterial, antiviral, diuretic and carminative properties. In addition, it is also used to treat heart failure, problems with the liver, anorexia, asthma and bronchitis. It is used as a spice and also finds use as medicine in culinary preparations and confectionery [6].

\section{Methods}

\section{Collection and identification of plant material}

The seeds were collected from the local market of East Sikkim. Then, it was identified and confirmed by following the standard literature studies. They were shade dried. The dried samples were ground to powder using electric blender.

\section{Pharmacognostical examination}

The macroscopical observations were carried out as per the standard methods to determine the shape, size, taste, odour and colour [7-10].

\section{Microscopical examination \\ Transverse section of seed}

Seed of the plant was sectioned by using blade; then, a clean glass slide was taken and a drop of glycerine water was placed in the centre of slide. In this, the section of seed was placed. The cover slip was placed by using the finger and thumb of the left hand and the edge of the cover slip was rested on the slide at the left hand edge of the drop. A dissecting needle was inserted under the right hand edge of the cover slip and the latter was rest on the needle. The cover slip was placed slowly onto the

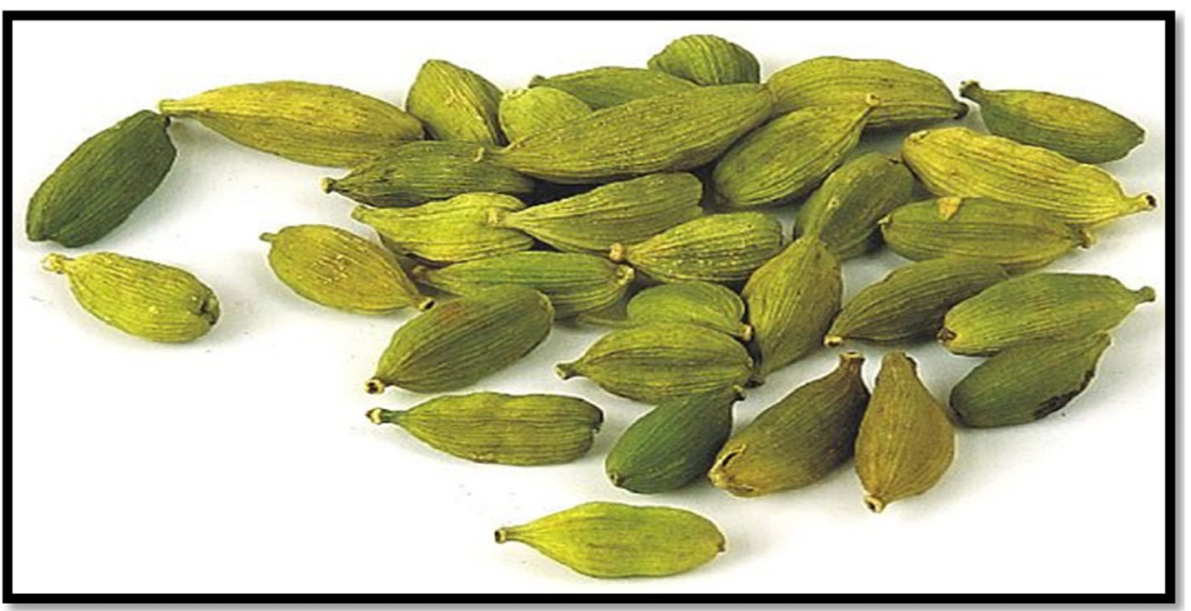

Fig. 1 Elettaria cardamomum (Linn.) seeds 
drop so that the liquid exactly fills the space between the slide and the cover slip without any air bubbles being trapped inside. The slide was placed in position on the stage of microscope. The T.S of the seed was seen by using $\times 10$ and $\times 45$ lens [11].

\section{Extractive value}

The extracts obtained by exhausting crude drugs are indicative of approximate measures of their chemical constituents. Taking into the consideration the diversity in chemical nature and properties of contents of drugs, various solvents are used for determination of extractive values [12].

\section{Water soluble extractive Method}

About $5 \mathrm{~g}$ of the coarse powdered air-dried seed was macerated with $100 \mathrm{ml}$ of chloroform water $(2.5 \mathrm{ml}$ in $1000 \mathrm{ml}$ water) in a stoppered flask for $24 \mathrm{~h}$. The content was shaking frequently for $6 \mathrm{~h}$. It was filtered through filter paper taking precaution against excessive loss of solvent. Twenty-five millilitres of water extract was evaporated to dryness in a tarred flat bottomed shallow dish. It was dried at $105^{\circ} \mathrm{C}$ and weighed. The percentage $\mathrm{w} / \mathrm{w}$ of water soluble extractive value was determined with reference to the air dried drug [13].

\section{Alcohol soluble extractive Method}

About $5 \mathrm{~g}$ of the coarsely powdered air-dried seed with $100 \mathrm{ml}$ of alcohol (95\% ethanol) in a stopper flask for 24 h. The content was shaking frequently for $6 \mathrm{~h}$. It was filtered through filter paper taking precaution against excessive loss of alcohol. Twenty-five millilitres of water extract was evaporated to dryness in a tarred flat bottomed shallow dish. It was dried at $105{ }^{\circ} \mathrm{C}$ and weighed. The percentage $\mathrm{w} / \mathrm{w}$ of alcohol soluble extractive value was determined with special standard reference to the air dried drug [14].

\section{Determination of moisture content Method}

About $5 \mathrm{~g}$ of the air-dried crude drug was accurately weighed in a tarred watch glass. The drug was kept in hot air oven at $105{ }^{\circ} \mathrm{C}$ and dried for a period until constant weight obtained. The difference in weight gives the moisture content of the drug [15-17].

\section{Determination of ash value Total ash: method $A$}

Two to $3 \mathrm{~g}$ of air-dried drug was weighed accurately in a tarred platinum or silica dish and incinerated at a temperature not exceeding $800{ }^{\circ} \mathrm{C}$ until free from carbon [18]. It was cooled and weighed. If a carbon free ash is not obtained, the charred mass was washed with hot water, the residue was collected on an ashless filter paper, and the residue was incinerated along with the filter paper until the ash is white or nearly white; the filtrate was added to the dish, evaporated to dryness. The percentage of total ash of the drug was calculated.

\section{Acid-insoluble ash: method B}

The ash (obtained from method A) was boiled with 25 $\mathrm{ml}$ of $2 \mathrm{M} \mathrm{HCL}$ acid for $5 \mathrm{~min}$, and the insoluble matter was collected in a Gooch crucible or on an ashless filter paper; it was washed with hot water, ignited, cooled in a desiccators and weighed. The percentage of acidinsoluble ash was calculated on the dried drug basis [19].

\section{Water soluble ash: method C}

The ash (of method A) was boiled with $25 \mathrm{ml}$ water for $5 \mathrm{~min}$, and the insoluble matter was collected in a Gooch crucible or on an ashless filter paper, it was washed with

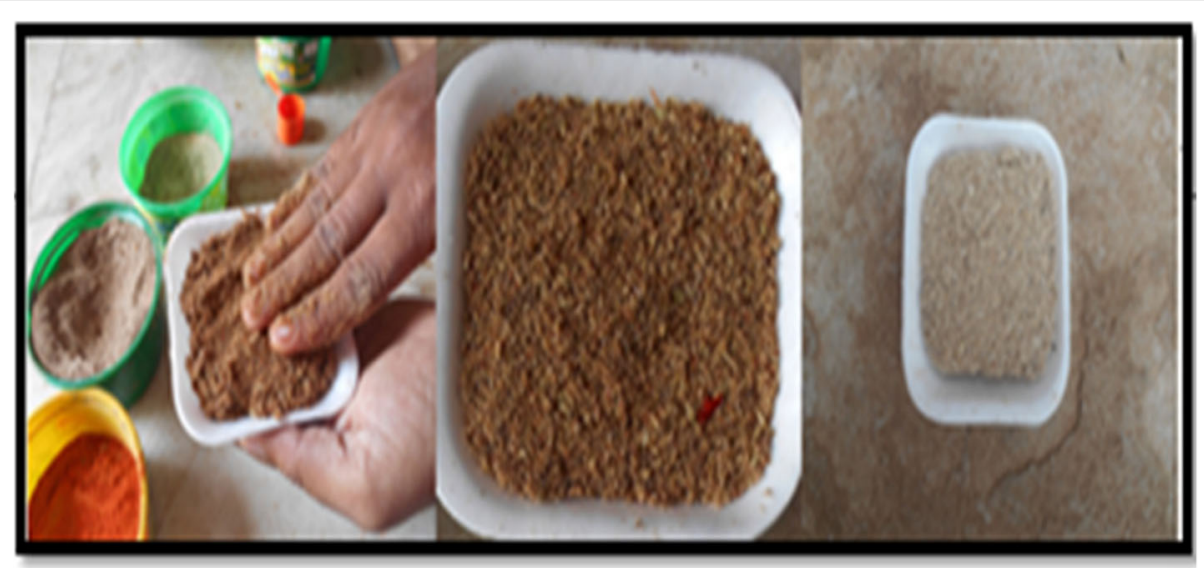

Fig. 2 Preparation of Elettaria cardamomum seed cake and drying 
Table 1 Average wet and dry weights of cardamom seed cakes

\begin{tabular}{|c|c|c|c|c|}
\hline SI. no. & Name of the sample & Average wet weight (g) & Average dry weight (g) & Amount lost (g) \\
\hline \multirow[t]{5}{*}{1.} & \multirow{5}{*}{$\begin{array}{l}\text { Cardamom powder } 2 \text { spoons } \\
\text { Wood powder } 2 \text { spoons } \\
\text { Chilli powder } 1 \text { spoon }\end{array}$} & (i) 50.48 & (i) 33.20 & \multirow[t]{5}{*}{19.44} \\
\hline & & (ii) 52.03 & (ii) 30.35 & \\
\hline & & (iii) 53.68 & (iii) 31.22 & \\
\hline & & (iv) 48.05 & (iv) 30.85 & \\
\hline & & (v) 50.70 & (v) 32.10 & \\
\hline
\end{tabular}

2.

Cardamom powder 1 spoon Wood powder 2 spoons Chilli powder 2 spoons

3.

Cardamom powder 2 spoons Wood powder 1 spoon Chilli powder 2 spoons

4.

Cardamom powder 3 spoons Wood powder 1 spoon Chilli powder 1 spoon

5.

Cardamom powder 1 spoon Wood powder 3 spoons Chilli powder 1 spoon

6.

Cardamom powder 1 spoon Wood powder 1 spoon Chilli powder 3 spoons

7.

Cardamom powder 3 spoons Wood powder $3 / 2$ spoons Chilli powder $1 / 2$ spoon

8.

Cardamom powder $7 / 2$ spoons Wood powder 1 spoon Chilli powder $1 / 2$ spoon

\section{Avg. 50.98}
(i) 38.30
(ii) 47.45
(iii) 42.24
(iv) 45.32
(v) 40.57

Avg. 42.77

(i) 50.27

(ii) 51.35

(iii) 48.92

(iv) 49.33

(v) 51.24

Avg. 31.54

(i) 25.20

12.09

(ii) 36.82

(iii) 27.92

(iv) 30.13

(v) 33.34

Avg. 30.68

(i) 38.92

12.40

(ii) 38.57

(iii) 36.32

(iv) 37.43

(v) 37.90

Avg. $\mathbf{5 0 . 2 2}$

Avg. 37.82
(i) 46.98
(ii) 47.54
(iii) 45.02
(iv) 47.25
(v) 46.30

(i) 34.01

(ii) 32.20

(iii) 32.24

(iv) 33.28

(v) 34.33

Avg. 46.61

Avg. 33.21
(i) 38.32
(i) 28.52
(ii) 37.34
(ii) 27.21
(iii) 38.55
(iii) 25.72
(iv) 36.22
(iv) 28.41
(v) 37.30
(v) 26.33

10.31

Avg. 37.54

Avg. 27.23
(i) 40.01
(ii) 45.42
(iii) 38.30
(iv) 42.21
(v) 46.52

(ii) 32.95

(iii) 33.51

(iv) 28.62

(v) 25.31

Avg. 42.49

Avg. 28.76
(i) 49.05
(ii) 45.57
(iii) 48.32
(iv) 49.27
(v) 47.53
(i) 34.42
(ii) 33.40
(iii) 32.23
(iv) 34.54
(v) 33.24

13.40

Avg. 47.94

Avg. 33.56

(i) 53.02

(i) 38.44

14.90 
Table 1 Average wet and dry weights of cardamom seed cakes (Continued)

\begin{tabular}{|c|c|c|c|c|}
\hline SI. no. & Name of the sample & Average wet weight (g) & Average dry weight (g) & Amo \\
\hline & & (iii) 52.22 & (iii) 38.45 & \\
\hline & & (iv) 53.34 & (iv) 36.33 & \\
\hline & & (v) 50.33 & (v) 35.90 & \\
\hline & & Avg. 52.23 & Avg. 37.33 & \\
\hline \multirow[t]{6}{*}{9.} & \multirow{6}{*}{$\begin{array}{l}\text { Cardamom powder } 3 / 2 \text { spoons } \\
\text { Wood powder } 3 \text { spoons } \\
\text { Chilli powder } 1 / 2 \text { spoon }\end{array}$} & (i) 42.23 & (i) 28.14 & 14.66 \\
\hline & & (ii) 40.43 & (ii) 25.34 & \\
\hline & & (iii) 43.25 & (iii) 28.52 & \\
\hline & & (iv) 42.52 & (iv) 27.99 & \\
\hline & & (v) 41.61 & (v) 26.73 & \\
\hline & & Avg. 42.00 & Avg. 27.34 & \\
\hline \multirow[t]{6}{*}{10.} & \multirow{6}{*}{$\begin{array}{l}\text { Cardamom powder } 1 \text { spoon } \\
\text { Wood powder } 7 / 2 \text { spoons } \\
\text { Chilli powder } 1 / 2 \text { spoon }\end{array}$} & (i) 37.34 & (i) 26.25 & 10.86 \\
\hline & & (ii) 36.02 & (ii) 27.12 & \\
\hline & & (iii) 37.55 & (iii) 26.26 & \\
\hline & & (iv) 35.32 & (iv) 24.33 & \\
\hline & & (v) 37.41 & (v) 25.37 & \\
\hline & & Avg. 36.72 & Avg. 25.86 & \\
\hline \multirow[t]{5}{*}{11.} & \multirow{5}{*}{$\begin{array}{l}\text { Cardamom powder } 2 \text { spoons } \\
\text { Wood powder } 5 / 2 \text { spoons } \\
\text { Chilli powder } 1 / 2 \text { spoon }\end{array}$} & (i) 44.32 & (i) 30.52 & 13.32 \\
\hline & & (ii) 40.57 & (ii) 28.10 & \\
\hline & & (iii) 43.43 & (iii) 27.25 & \\
\hline & & (iv) 44.32 & (iv) 32.34 & \\
\hline & & (v) 42.73 & (v) 30.55 & \\
\hline
\end{tabular}

Avg. $43.07 \quad$ Avg. 29.75

12. Cardamom powder $5 / 2$ spoons

Wood powder 2 spoons

Chilli powder $1 / 2$ spoon
(i) 49.52
(ii) 48.79
(iii) 49.83
(iv) 47.54
(v) 48.32

(i) 33.43

16.57

(ii) 30.55

(iii) 33.72

(iv) 32.35

(v) 31.12

Avg. 48.80

Avg. 32.23

13. Cardamom powder $5 / 2+1 / 4$ spoons

(i) 54.14

(i) 38.72

15.91

Wood powder 2 spoons

Chilli powder 1/4 spoon

(ii) 52.31

(iii) 54.29

(ii) 37.57

(iii) 38.49

(iv) 55.84

(iv) 37.62

(v) 53.50

(v) 38.12

Avg. 54.01

Avg. 38.10

14.

Cardamom powder 2 spoons Wood powder $5 / 2+1 / 4$ spoons Chilli powder $1 / 4$ spoon
(i) 49.54
(ii) 47.57
(iii) 48.32
(iv) 49.19
(v) 49.24

34.79

(ii) 33.59

(iii) 34.70

(iv) 32.24

(v) 33.42

Avg. 48.77

Avg. 33.74

15. Cardamom powder 3 spoons Wood powder $3 / 2+1 / 4$ spoons

(i) 55.54

(i) 39.49

15.46 Chilli powder $1 / 4$ spoon

(ii) 38.51

(iii) 39.03

(iv) 40.82 
Table 1 Average wet and dry weights of cardamom seed cakes (Continued)

\begin{tabular}{|c|c|c|c|c|}
\hline SI. no. & Name of the sample & Average wet weight (g) & Average dry weight (g) & Amount lost $(\mathrm{g})$ \\
\hline & & (v) 54.72 & (v) 38.55 & \\
\hline & & Avg. 54.74 & Avg. 39.28 & \\
\hline \multirow[t]{5}{*}{16.} & \multirow{5}{*}{$\begin{array}{l}\text { Cardamom powder } 3 / 2+1 / 4 \text { spoons } \\
\text { Wood powder } 3 \text { spoons } \\
\text { Chilli powder } 1 / 4 \text { spoon }\end{array}$} & (i) 42.54 & (i) 28.79 & \multirow[t]{5}{*}{12.62} \\
\hline & & (ii) 40.38 & (ii) 29.55 & \\
\hline & & (iii) 43.05 & (iii) 30.32 & \\
\hline & & (iv) 42.55 & (iv) 29.97 & \\
\hline & & (v) 41.74 & (v) 28.52 & \\
\hline
\end{tabular}

Avg. 42.05

Avg. 29.43

hot water, and ignited for $15 \mathrm{~min}$ at a temperature not exceeding $800^{\circ} \mathrm{C}$. The weight of the insoluble matter was subtracted from the weight of the ash; water-soluble ash reflects the difference in weight. On the dried drug basis, the percentage of water soluble ash was then measured [20].

\section{Preparation of cakes}

Fifteen to sixteen cakes of different weight with different proportion of the components were prepared (Fig. 2). Wet weight of cakes was taken. For the determination of dry weight, cakes were allowed to dry in the sun for $96 \mathrm{~h}$ and dry weight was taken [21]. Natural binder (wood powder-mixed powder from Alnus, Abies tress) was purchased from local vendor. To increase the efficacy of the replicates cakes, chilli powder with various proportions was mixed and natural gum collected from gum Arabic tree from local area was used as adhesive.

Preparation of cardamom seed cakes in combination with natural binder

For the preparation of mosquito repellent coils, different fillers can be used; however, in this study, natural binder was utilized. Mosquito repellent cakes were prepared by plating total 5 table spoons ( 1 table spoon $=20 \mathrm{ml}$ ) of cardamom seed powder, chilli powder and wood powder with various proportion along with gum in thermocol plates $[22,23]$. Wet weight of cakes and dry weight (after $96 \mathrm{~h}$ ) of prepared cakes were recorded (Table 1). A significant weight loss is recorded, i.e. $14.06 \mathrm{~g}$ in all combinations.

\section{Evaluation of cardamom seed cakes}

The efficacy of prepared cardamom seed cakes were evaluated on three different parameters such as flammability, burning time and mosquito repellence test [24].

a) Flammability test and burning time

To observe the flammability of the cakes, the cakes were burnt using candles (Fig. 3). The quantity of ash, irritation produced by different combination of cakes and the time taken to burn completely were recorded (Table 2). Each combination's ash weights and their burning time have been documented [25]. Residual percentages were determined based on ash weight and dry weight. The percentage residual is determined by:

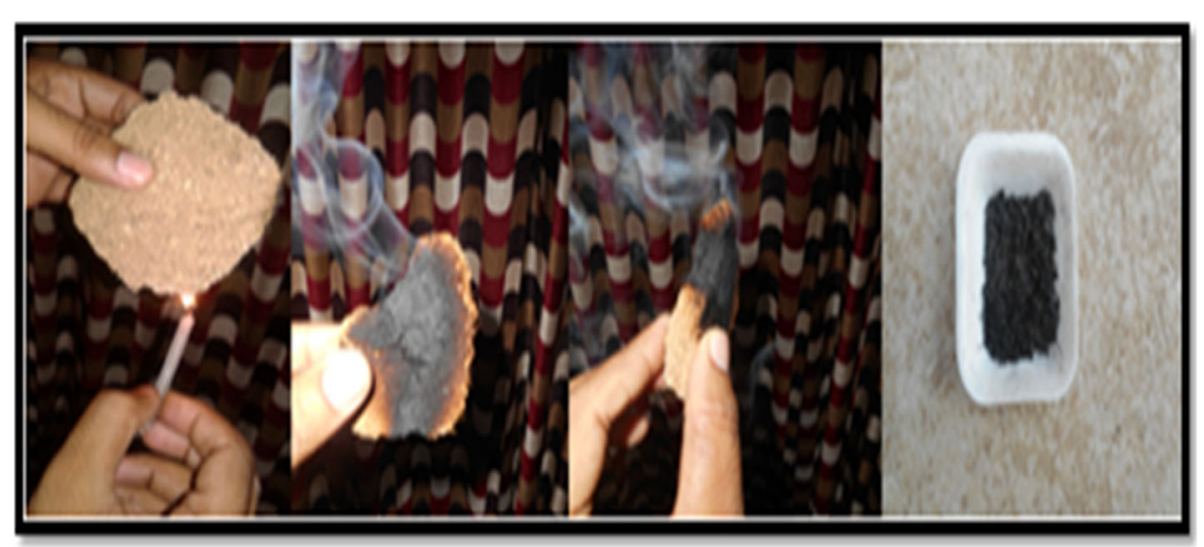

Fig. 3 Burning of Elettaria Cardamomum seed cake and its ash 
Table 2 Parameters to check flammability of cardamom seed cakes

\begin{tabular}{|c|c|c|c|c|c|c|c|}
\hline $\begin{array}{l}\text { SI } \\
\text { No. }\end{array}$ & Name of the sample & $\begin{array}{l}\text { Dry weight } \\
\text { (g) }\end{array}$ & $\begin{array}{l}\text { Ash weight } \\
\text { (g) }\end{array}$ & $\begin{array}{l}\text { Time taken to burn } \\
\text { (min) }\end{array}$ & $\begin{array}{l}\text { Residual } \\
(\%)\end{array}$ & Irritation & Remarks \\
\hline 1. & $\begin{array}{l}\text { Cardamom powder } 2 \text { spoons } \\
\text { Wood powder } 2 \text { spoons } \\
\text { Chilli powder } 1 \text { spoon }\end{array}$ & 31.54 & 5.58 & 80 & 17.69 & High irritation & Fully burnt \\
\hline 2. & $\begin{array}{l}\text { Cardamom powder } 1 \text { spoon } \\
\text { Wood powder } 2 \text { spoons } \\
\text { Chilli powder } 2 \text { spoons }\end{array}$ & 30.68 & 5.76 & 75 & 18.77 & $\begin{array}{l}\text { Very high } \\
\text { irritation }\end{array}$ & Fully burnt \\
\hline 3. & $\begin{array}{l}\text { Cardamom powder } 2 \text { spoons } \\
\text { Wood powder } 1 \text { spoon } \\
\text { Chilli powder } 2 \text { spoons }\end{array}$ & 37.82 & 6.62 & 78 & 17.50 & $\begin{array}{l}\text { Very high } \\
\text { irritation }\end{array}$ & Fully burnt \\
\hline 4. & $\begin{array}{l}\text { Cardamom powder } 3 \text { spoons } \\
\text { Wood powder } 1 \text { spoon } \\
\text { Chilli powder } 1 \text { spoon }\end{array}$ & 33.21 & 8.45 & 83 & 25.44 & High irritation & $\begin{array}{l}\text { Not fully } \\
\text { burnt }\end{array}$ \\
\hline 5. & $\begin{array}{l}\text { Cardamom powder } 1 \text { spoon } \\
\text { Wood powder } 3 \text { spoons } \\
\text { Chilli powder } 1 \text { spoon }\end{array}$ & 27.23 & 3.79 & 73 & 13.91 & High irritation & Fully burnt \\
\hline 6. & $\begin{array}{l}\text { Cardamom powder } 1 \text { spoon } \\
\text { Wood powder } 1 \text { spoon } \\
\text { Chilli powder } 3 \text { spoons }\end{array}$ & 28.76 & 5.79 & 76 & 20.13 & $\begin{array}{l}\text { Very high } \\
\text { irritation }\end{array}$ & Fully burnt \\
\hline 7. & $\begin{array}{l}\text { Cardamom powder } 3 \text { spoons } \\
\text { Wood powder } 3 / 2 \text { spoons } \\
\text { Chilli powder } 1 / 2 \text { spoon }\end{array}$ & 33.56 & 5.96 & 82 & 17.75 & Less irritation & Fully burnt \\
\hline 8. & $\begin{array}{l}\text { Cardamom powder } 7 / 2 \text { spoons } \\
\text { Wood powder } 1 \text { spoon } \\
\text { Chilli powder } 1 / 2 \text { spoon }\end{array}$ & 37.33 & 8.02 & 97 & 21.48 & Less irritation & $\begin{array}{l}\text { Not fully } \\
\text { burnt }\end{array}$ \\
\hline 9. & $\begin{array}{l}\text { Cardamom powder } 3 / 2 \text { spoons } \\
\text { Wood powder } 3 \text { spoons } \\
\text { Chilli powder } 1 / 2 \text { spoon }\end{array}$ & 27.34 & 4.25 & 80 & 15.54 & Less irritation & Fully burnt \\
\hline 10. & $\begin{array}{l}\text { Cardamom powder } 1 \text { spoon } \\
\text { Wood powder } 7 / 2 \text { spoons } \\
\text { Chilli powder } 1 / 2 \text { spoon }\end{array}$ & 25.86 & 3.88 & 75 & 15.00 & Less irritation & Fully burnt \\
\hline 11. & $\begin{array}{l}\text { Cardamom powder } 2 \text { spoons } \\
\text { Wood powder } 5 / 2 \text { spoons } \\
\text { Chilli powder } 1 / 2 \text { spoon }\end{array}$ & 29.75 & 5.62 & 84 & 18.89 & Less irritation & Fully burnt \\
\hline 12. & $\begin{array}{l}\text { Cardamom powder } 5 / 2 \text { spoons } \\
\text { Wood powder } 2 \text { spoons } \\
\text { Chilli powder } 1 / 2 \text { spoon }\end{array}$ & 32.23 & 6.34 & 85 & 19.67 & Less irritation & Fully burnt \\
\hline 13. & $\begin{array}{l}\text { Cardamom powder } 5 / 2+1 / 4 \\
\text { spoons } \\
\text { Wood powder } 2 \text { spoons } \\
\text { Chilli powder } 1 / 4 \text { spoon }\end{array}$ & 38.10 & 8.77 & 95 & 23.01 & No irritation & $\begin{array}{l}\text { Not fully } \\
\text { burnt }\end{array}$ \\
\hline 14. & $\begin{array}{l}\text { Cardamom powder } 2 \text { spoons } \\
\text { Wood powder } 5 / 2+1 / 4 \text { spoons } \\
\text { Chilli powder } 1 / 4 \text { spoon }\end{array}$ & 33.74 & 6.55 & 90 & 19.41 & No irritation & Fully burnt \\
\hline 15. & $\begin{array}{l}\text { Cardamom powder } 3 \text { spoons } \\
\text { Wood powder } 3 / 2+1 / 4 \text { spoons } \\
\text { Chilli powder } 1 / 4 \text { spoon }\end{array}$ & 39.28 & 9.22 & 92 & 23.47 & No irritation & $\begin{array}{l}\text { Not fully } \\
\text { burnt }\end{array}$ \\
\hline 16. & $\begin{array}{l}\text { Cardamom powder } 3 / 2+1 / 4 \\
\text { spoons } \\
\text { Wood powder } 3 \text { spoons } \\
\text { Chilli powder } 1 / 4 \text { spoon }\end{array}$ & 29.43 & 4.43 & 65 & 15.05 & No irritation & Fully burnt \\
\hline
\end{tabular}

Residual $(\%)=$ Ash weight $/$ dry weight $\times 100$

b) Mosquito repellency test

Mosquito repellency test was done by simply selecting the mosquito-prone areas in the evening and night period such as bushes, shrubs, laboratory corners and cafeteria [26] (Table 3). The public remarks were noted down after allowing them to burn the cakes and checking if the mosquitoes are present or escaping away from the burning cakes. 
Table 3 Mosquito repellency test in different areas of Department of Zoology

\begin{tabular}{llll}
\hline SI No. & Areas & Reports given by people & Remarks \\
\hline $\mathbf{1 .}$ & Department premises & Smoke caused irritation & Mosquito repelled \\
$\mathbf{2 .}$ & Class room corners & Mosquitoes escaped & Mosquito repelled \\
$\mathbf{3 .}$ & Cafeteria & Mosquitoes moved outside & Mosquito repelled \\
$\mathbf{4 .}$ & Laboratory corners & Smoke caused irritation & Mosquito repelled \\
\hline
\end{tabular}

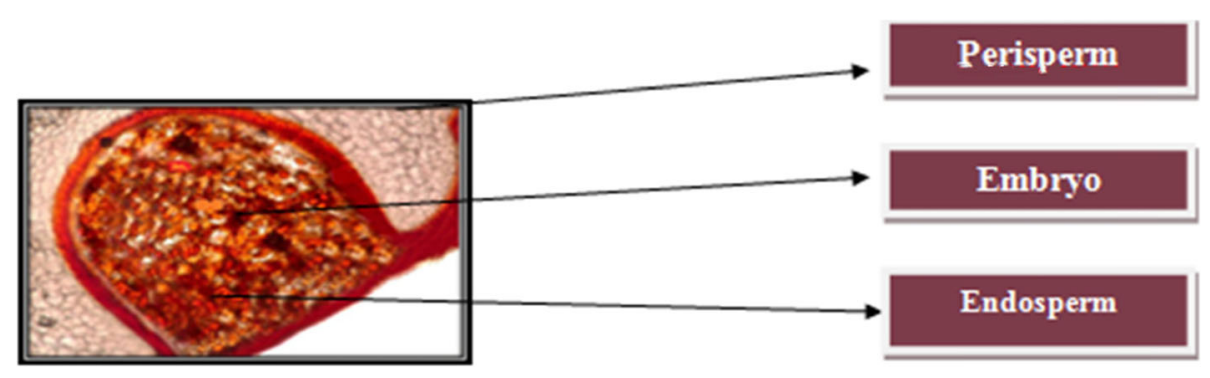

Fig. 4 TS of embryo

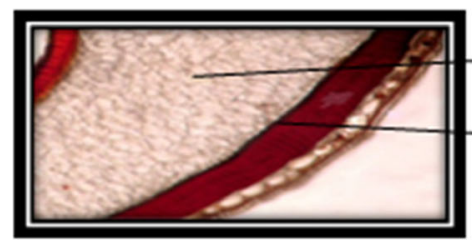

Perisperm

\section{Testa}

Fig. 5 T.S. of testa and perisperm 


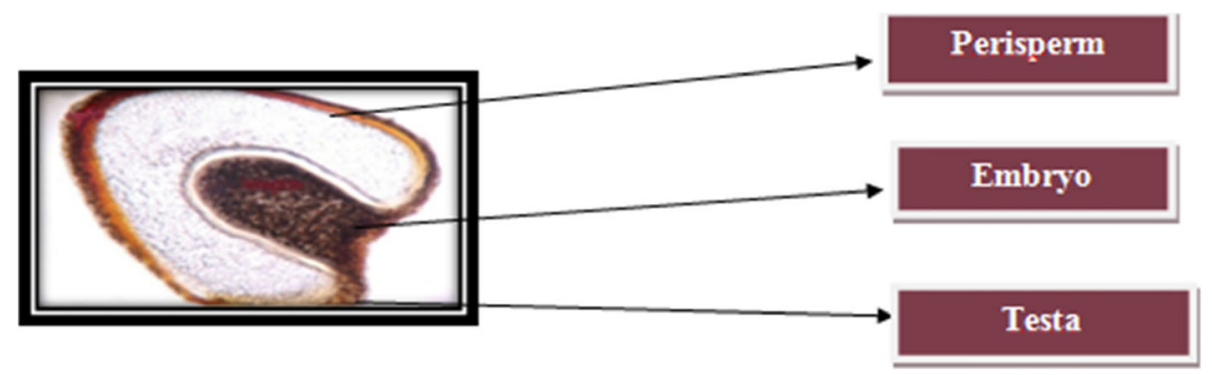

Fig. 6 Whole section showing testa, perisperm and embryo

\section{Results}

\section{Pharmacognostical}

The pharmacognostical results are shown in Figs. 4, 5 and 6 .

\section{Proximate analysis}

The extractive values, moisture contents and ash values are shown in Tables 4, 5 and 6.

\section{Discussion}

Insects are also known for their aggravating characteristics of biting, stinging, contaminating and spreading disease, so people have long found ways to contain them. We do not need all insect life to be killed. Birds, reptiles and mammals are supplied with food by insects and several help pollinate plants [27]. Health stores sell a range of bug repellent based on essential oil that are sufficiently diluted to avoid skin irritation. Essential oils should be used carefully by pregnant women. The macroscopic analysis is a morphological summary of the naked eye or magnifying lens of the plant components. The microscopic research is the anatomical study conducted by taking a suitable part of the plant parts under analysis [28]. Each distinguishing characters are noted down. To obtain clear sections of TS phloroglucinol, $\mathrm{HCL}$ are used. Estimation of extractive values determines the amount of the active constituents in a given amount of plant material when extracted with a particular solvent. Extractions of any crude drug containing a specific solvent create a solution containing various phytoconstituents. The structures of these phytoconstituents depend on the essence of the drug and the solvent used. It also provides an indication of whether or not the crude drug is depleted. To prevent the growth of bacteria, yeast or fungi during storage, the moisture content

Table 4 Extractive value

\begin{tabular}{lll}
\hline Sl. No & Type of extract & Percentage (W/W) \\
\hline 1 & Alcohol & $4.88 \%$ \\
2 & Water & $40 \%$ \\
\hline
\end{tabular}

of drugs should be at a minimum level. Ash values are used to determine crude drug content and purity. The presence of various impurities such as carbonate, oxalate and silicate is suggested. To estimate the amount of inorganic compounds found in medicines, water soluble ash is used. From the tests experiments, herbal-based mosquito repellents showed promising result of its consistent burning ability, less residual percentage and no irritation due to the use of natural wood powder, natural gum and combination of herbal ingredients.

\section{Conclusion}

Malaria, dengue fever and filariasis, which are transmitted via mosquito bites, are a major public health issue in tropical regions, especially in Africa and Asia. Therefore, for successful control of these diseases, individual mosquito bites need to be avoided. Instead of commercially available synthetic insecticides and repellents such as organophosphorus, carbamate, N,N-diethyl-3-methylbenzamide (DEET) and dichloro diphenyl trichloroethane (DDT), which are carcinogenic and non-eco-friendly, the use of mosquito repellent naturally obtained from medicinal plants is an efficient and healthy process. The use of synthetic chemicals to monitor insects and arthropods currently poses many environmental and human health issues. Using natural goods that have good effectiveness and are environmentally friendly is an option. Among those chemicals, essential oils from plants belonging to several species have been extensively tested as a valuable natural resource to evaluate their repellent properties. Further detailed research, however, needs to be carried out by collecting unique numbers of mosquitoes in a glass chamber covered with cloth sieve and exposing them to the smoke created by the herbal product with

Table 5 Moisture content

\begin{tabular}{lllll}
\hline $\begin{array}{l}\text { Weight } \\
\text { of drug }\end{array}$ & $\begin{array}{l}\text { Initial wt. of drug } \\
\text { + petridish (g) }\end{array}$ & $\begin{array}{l}\text { Constant wt. } \\
\text { after drying (g) }\end{array}$ & $\begin{array}{l}\text { Loss on } \\
\text { drying } \\
\text { (g) }\end{array}$ & $\begin{array}{l}\text { Moisture } \\
\text { content }\end{array}$ \\
\hline $10 \mathrm{gm}$ & 64.92 & 64.06 & 0.86 & $8.6 \%$ \\
\hline
\end{tabular}


Table 6 Determination of ash value

\begin{tabular}{lll}
\hline Sl. no & \%W/W & \\
\hline 1. & Total ash & 5 \\
2. & Acid insoluble ash & 1.5 \\
3. & Water soluble ash & 3.5 \\
\hline
\end{tabular}

varying concentrations and documenting mortality time and comparing them with chemical-based formula in the artificial. Because of its consistent burning ability with no irritating smoke and low residual percentage and high mosquito repellent power, it can therefore be considered good mosquito repellent.

\section{Acknowledgements}

The authors are grateful to the host institutes-School of Skill Building-SRM University Sikkim, Department of Pharmaceutical Sciences, North Bengal University, West Bengal and Government Pharmacy College, Sajong-Sikkim, and also to Himalayan Pharmacy College, Majhitar to give such advanced facilities such as laboratory facilities, chemical utilities, sophisticated instruments, man powder, sound and friendly environment, etc., to collect the significant interpretational data for this investigational work. Thanks to entire colleges' team especially Dr. P. Pal and Mr. S. Bhutia, for their kind guidance, scientific instructions, formatting and designing all the essential information to make my drafted work into a valuable research manuscript

\section{Authors' contributions}

R.D, responsible for Selection of the research work and major data collection by trial and error methods. P.P, responsible for the guidance of the work till the end. S.B, contributed for drafting, designing, formatting and referencing of this research article and communicating with scientific esteemed journal having good reputation in the scientific fields. S.B plays centre part for the overall formatting and drafting of this scientific research article. All authors have read and approved the manuscript.

\section{Funding}

Not applicable.

\section{Availability of data and materials}

Data and materials are available upon request.

\section{Ethics approval and consent to participate}

Not applicable.

\section{Consent for publication}

Not applicable.

\section{Competing interests}

The author has no conflict of interest to disclose.

\section{Author details}

${ }^{1}$ School of Skill Building, SRM University Sikkim, Gangtok 737102, India. ${ }^{2}$ Department of Pharmaceutical Technology, University of North Bengal, Siliguri, West Bengal 734013, India. ${ }^{3}$ Department of Pharmacognosy, Government Pharmacy College, Government of Sikkim, Sikkim University, Sajong, Rumtek, East Sikkim, Gangtok 737135, India.

Received: 14 September 2020 Accepted: 26 December 2020 Published online: 11 January 2021

\section{References}

1. Aviles G, Paz MV, Rangeon G, Ranaivoarisoa MY, Verzeri N, Roginski S, Baroni P, Enria D (2003) Laboratory surveillance of dengue in Argentina, 19952001. Emerg Infect Dis 9(6):738-742. https://doi.org/10.3201/eid0906.020483

2. Carbajo AE, Schweigmann N, Curto SI, de Garin A, Bejaran R (2001) Dengue transmission risk maps of Argentina. Trop Med Int Health 6(3):170-183. https://doi.org/10.1046/j.1365-3156.2001.00693.x

3. Gouge DH, Li S, Nair S, Walker K, Bibbs CS (2017) Mosquito and tick repellents. University of Arizona, Tucson
4. Larsen K (1996) A preliminary checklist of the Zingiberaceae of Thailand. Thai Forest Bull Bot (24):35-49

5. Chou JT, Rossignol PA, Ayres JW (1997) Evaluation of commercial insect repellents on human skin against Aedes aegypti (Diptera: Culicidae). J Med Entomol 34(6):624-630. https://doi.org/10.1093/jmedent/34.6.624

6. Cardamom: Scientists, Njallani developers fight. Commodity Online (2008). http://nif.org.in/innovation/New_cardamom_variety_-Njallani/84

7. Khandelwal K (2008) Practical pharmacognosy. Pragati Books Pvt. Ltd

8. Sharma NK, Ahirwar D, Gupta S, Jhade D (2011) Pharmacognostic standardization, physico and phytochemical evaluation of Nigella sativa Linn. seed. Int J Pharm Sci Res 2(3):713-718. https://doi.org/10.13040/JPSR.0975-8232.2(3).713-18

9. Bigoniya P, Singh CS, Shukla A (2011) Pharmacognostical and physicochemical standardization of ethnopharmacologically important seeds of Lepidium sativum Linn. and Wrightia tinctoria R. Br. Indian I Nat Prod Resour 2(4):464-471

10. Bothara SB, Singh S (2012) Pharmacognostical studies of seeds on some plants belonging Chhattisgarh. Pharmacog J 4(28):24-30. https://doi.org/10. 17660/ACTAHORTIC.2005.675.18

11. Liao JP, Wu QG (2000) A preliminary study of the seed anatomy of Zingiberaceae. Bot J Linn Soc 134(1-2):287-300. https://doi.org/10.1111/j. 1095-8339.2000.tb02355.x

12. Sharma A, Sharma AK, Chand T, Khardiya M, Yadav KC (2013) Preliminary phytochemical evaluation of seed extracts of Cucurbita maxima duchense. J Pharmacog Phytochem 2(3):62-65

13. Bigoniya P, Singh CS, Srivastava B (2012) Pharmacognostical and physico-chemical standardization of Syzygium cumini and Azadirachta indica seed. Asian Pac J Trop Biomed 2(1):S290-S295. https:/doi.org/10.1016/S2221-1691(12)60176-2

14. Sasmal S, Majumdar S, Gupta M, Mukherjee A, Mukherjee PK (2012) Pharmacognostical, phytochemical and pharmacological evaluation for the antipyretic effect of the seeds of Saraca asoca Roxb. Asian Pac J Trop Biomed 2(10):782-786. https://doi.org/10.1016/S2221-1691(12)60229-9

15. Gokhale MS (2008) Pharmacognosy. Pragati Books Pvt. Ltd

16. Zuhair AH, Sayeh BE, Ameen AH (1996) Pharmacological studies of cardamom oil in animals. Pharmacol Res 34:79-82. https://doi.org/10.1006/phrs.1996.0067

17. Murti Y, Yogi B, Pathak D (2010) Pharmacognostic standardization of leaves of Calotropis procera (Ait.) R. Br.(Asclepiadaceae). Int J Ayurveda Res 1(1):14. https://doi.org/10.4103/0974-7788.59938

18. Mulla SK, Paramjyothi S (2010) Preliminary pharmacognostical and phytochemical evaluation of Portulaca quadrifida Linn. Int J Pharm Tech Res 2(3):1699-1702 https://www.cabdirect.org/cabdirect/abstract/20103248548

19. Bhattacharya S, Zaman MK (2009) Pharmacognostical evaluation of Zanthoxylum nitidum bark. Int J Pharm Tech Res 1(2):292-298

20. Kumar D, Gupta J, Kumar S, Arya R, Kumar T, Gupta A (2012) Pharmacognostic evaluation of Cayratia trifolia (Linn.) leaf. Asian Pac J Trop Biomed 2(1):6-10. https://doi.org/10.1016/S2221-1691(11)60180-9

21. Mandavgane SA, Pattalwar W, Kalambe AR (2005) Development of cow dung based herbal mosquito repellent. Nat Prod Radiance 4(4):270-273 http://nopr.niscair.res.in/handle/123456789/8105

22. Phal D, Patil S, Naik R (2012) Concentration of d-trans allethrin in air after complete smoldering of mosquito repellent coil manufactured using different fillers. Inter J Biol Pharm Allied Sci 1(9):1312-1321 Corpus ID:138472657

23. Rani N, Aakanksha W, Vidyarthi SA, Pandey DM (2013) Study of Citronella leaf based herbal mosquitorepellents using natural binders. Curr Res Microbiol Biotechnol 1(3):98-103

24. Das NG, Baruah I, Talukdar PK, Das SC (2003) Evaluation of botanicalsas repellents against mosquitoes. J Vector Borne Dis 40:49-53 PMID: 15119071

25. Yang P, Ma Y (2005) Repellent effect of plant essential oils against Aedesalbopictus. J Vector Ecol 30(2):231-234 PMID: 16599157

26. Govindarajan M (2011) Larvicidal and repellent properties of someessential oils against Culextritaeniorhynchus Giles and Anopheles subpictus Grassi (Diptera: Culicidae). Asian Pac J Trop Med 4(2):106-111. https://doi.org/10. 1016/S1995-7645(11)60047-3

27. Ansari MA, Vasudevan P, Tandon M, Razdan RK (2000) Larvicidal andmosquito repellent action of peppermint (Mentha piperita) oil. Bioresour Technol 71(3):267-271. https://doi.org/10.1016/S0960-8524(99)00079-6

28. Trongtokit $Y$, Rongsriyan $Y$, Komalamisra N (1995) Comparative repellency of 38 essential oils against mosquitobites. Phytother Res 19(4):303-309. https:// doi.org/10.1002/ptr.1637

\section{Publisher's Note}

Springer Nature remains neutral with regard to jurisdictional claims in published maps and institutional affiliations. 